\title{
Analisis Kepercayaan dan Kualitas Situs pada Minat Beli Produk E-Commerce Bukalapak
}

\author{
Ani Solihat $^{1 *}$, Hana Friska Tampubolon ${ }^{2}$, Rani Rahmayani ${ }^{3}$, Andry Trijumansyah ${ }^{4}$ \\ Universitas BSI Bandung \\ Jl. Terusan Sekolah No.1-2, Cicaheum, Kec. Kiaracondong, Kota Bandung, Jawa Barat \\ aniaja2608@gmail.com*
}

\begin{abstract}
Abstrak- Penelitian ini bertujuan untuk mengetahui dan menganalisis kepercaya konsumen dan kualitus situs pada minat beli produk e-commerce Bukalapak. Terdapat tiga identifikasi masalah yaitu mengukur minat beli produk, tingkat kepercayaan konsumen lebih rendah dibandingkan dengan e-commerce lain dan tingkat kualitas situs masih memiliki kekurangan. Penelitian ini merupakan jenis penelitian yang betujuan menganalisis pengaruh antar satu variabel penelitian dengan variabel lainnya. Metode yang digunakan adalah metode desain deskriptif, verivikatif, dan sample kepada 100 responden dari masyarakat yang pernah belanja di bukalapak minimal satu kali ataupun di situs e-commerce lainnya. Penyebaran Kuesioner melalui google form kepada pengguna internet dan yang sudah pernah membuka situs Bukalapak. Hasil penguji menunjukan bahwa kepercayaan konsumen berpengaruh positif dan signifikan terhadap minat beli dan kualitas situs berpengaruh positif dan signifikan terhadap minat beli. Dan secara simultan kepercayaan dan kualitas situs berpengaruh signifikan terhadap minat beli.
\end{abstract}

\section{Kata Kunci : Kepercayaan, Kualitas Situs, Minat beli}

Abstract- The purpose of this study is to examine the effects of consumer trust and website quality on purchase intention in Bukalapak e-commerce platform. Data were collected through questionnaires distributed online by means of Google Forms. 100 sample respondents were selected purposively. The sample criterion is having an experience of buying products from Bukalapak at least once. The results of data analysis revealed that consumer trust and website quality had significant positive influence on purchase intention both partially and simultaneously.

Keyword: consumer trust, website quality, purchase intention

\section{PENDAHULUAN}

Perkembangan bisnis online di Indonesia sangat pesat, hal ini menandakan era pemanfaatan teknologi informasi sudah mulai diakui keberadaannya. Bisnis online atau yang biasa disebut dengan e-commerce semakin banyak di Indonesia hal ini disebabkan perkembangan internet. Mudahnya akses internet baik melalui wifi ataupun perangkat gadget memudahkan masyarakat untuk mengakses informasi mengenai suatu produk atau jasa yang dicarinya ditambah dengan gencarnya promosi yang dilakukan oleh perusahaan $e$ commerce dalam menawarkan barang atau jasanya dengan menawarkan berbagai macam kemudahan bagi masyarakat [1].

Bisnis berbasis online saat ini berada pada sorotan utama semua pihak karena sedang mengalami pertumbuhan pada saat ini dan prediksi pertumbuhan yang akan terjadi dimasa yang akan datang. Pada tahun
2020 pasar e-commerce Indonesia diprediksi akan memiliki nilai US\$130 miliar. Perubahan perilaku masyarakat dalam e-commerce merupakan tantangan tersendiri bagi perusahaan agar dapat memenuhi kebutuhan dan keinginan konsumennya. [1]. Di Indonesia sendiri terdapat beberapa situs jual beli online yang mendominasi situs jual beli online seperti Bukalapak, Lazada, Tokopedia, Blibli, Shoppie dan masih banyak lagi. Situs tersebut memiliki penawaran produk yang berbeda-beda mulai menawarkan produk hasil UKM, pelapak besar, superstore hingga barangbarang bekas pakai. Bukalapak menyediakan sarana transaksi dari pelanggan dimanapun dan siapapun dapat membuka toko online untuk melayani calon pembeli di seluruh Indonesia. Bukalapak sendiri dalam mengenalkan situsnya tidak dilakukan secara pasif melainkan dengan memanfaatkan layanan search 
engineoptimazion, word of mount dari penggunanya, komunitas, pelapak serta pemanfaatan iklan berbayar yang disediakan google (Jarrell D. Collier, Michael P. Davenport,2017).

Berdasarkan pemaparan tersebut dapat diketahui bahwa Bukalapak menggunakan model bisnis situs pihak ketiga, dimana situs sebagai perantara antar penggunanya dari segi pelapak hingga pelanggannya. Situs pihak ketiga semakin dituntut untuk selalu siap dalam menghadapi era persaingan diantara para situs pihak ketiga. Setiap situs pihak ketiga dituntut untuk memberikan kepercayaan terhadap para pelanggan mengingat kebutuhan pelanggan yang semakin berkembang dan menginginkan segala proses dapat dilakukan dengan mudah dan cepat. Menurut azalea_traveler (2016) di dalam forum bukalapak, dalam meningkatkan minat beli pelapak harus pintar menentukan harga dan margin yang akan didapat. Harga yang dipajang dalam website adalah harga yang dikeluarkan pelapak setelah menghitung besar margin yang didapat. Panji Wicaksono di dalam forum bukalapak memaparkan bahwa penambahan fitur negosiasi di bukalapak sangat menarik dan menyebabkan konsumen tertarik untuk membeli di bukalapak (forum bukalapak.com). Zaki memaparkan dalam forum Bukalapaknya, Bukalapak memberikan jangka waktu untuk pelapaknya mengirim transaksi dalam tiga hari, jika pelapak tidak mengirim barang sesuai waktu yang ditentukan, maka dana akan kembali kedompet costumerdi Bukalapak.

Bukalapak memaparkan panduan dalam situsnya untuk meningkatkan reputasi, semakin banyak feedback positif yang diterima oleh pelapak, maka semakin tinggi reputasi yang akan diterima oleh pelapak. Dari reputasi itu menyebabkan tingkat 12 kepercayaan costumer meningkat. Tetapi, penipuan juga terjadi pada Bukalapak sendiri, tidak sedikit penipuan terjadi pada Bukalapak. Karena mudahnya dan jujur dan benar-benar bertujuan dalam penipuan. Pada situs Bukalapak, setiap pelapak harus mengumpulkan feedback positif pada setiap penjualan, hal ini mempengaruhi reputasi pelapak. Setiap pelapak kemungkinan mendapatkan feedback negatif sebesar 10\% dari keseluruhan feedback yang didapat. Berdasarkan pemaparan tersebut dapat disimpulkan bahwa, semakin tinggi feedback positif yang diterima oleh pelapak maka akan berpengaruh baik untuk situs Bukalapak dan sebaliknya apabia semakin tinggi feedback negatif yang diterima oleh pelapak maka akan berpengaruh buruk untuk situs Bukalapak.

Sejak awal berdirinya sampai saat ini Bukalapak telah menyedot sekitar 260 ribu pengunjung per harinya (www.SWA.co.id) dan melayani transaksi dengan nilai total 500 juta rupiah tiap harinya. Namun dengan strategi bisnis dan inovasi yang dilakukan, Bukalapak baru mampu menduduki peringkat $\mathrm{k}$ diantara situs lainnya yang disebutkan di atas dan pada peringkat 22 dari seluruh situs yang ada di Indonesia. Bukalapak.com juga baru mampu mengkonversikan $1 \%$ dari total pengunjung untuk melakukan transaksi disana (id.techinasia.com). Dari data tersebut diketahui bahwa secara garis besar, Bukalapak masih cukup tertinggal dibanding situs lain dan belum mampu mengubah pengunjung situsnya menjadi pembeli yang melakukan transaksi disana.

Kepercayan konsumen terbentuk dengan dua cara berbeda, yaitu ada formasi langsung dan tidak langsung. Pada formasi langsung keprcayaan konsumen terbentuk tanpa terjadi keadaan lain sebelumnya. Kepercayaan terbentuk sebelum kita mengambil sikap atau keputusan yaitu saat komsumen melakukan pemrosesan informasi baik dari produsen langsung yaitu iklan atau informasi dari sesama konsumen. Pada informasi tidak langsung terjadi sebaliknya yaitu jika sebuah keaadan atau sikap menimbulkan penciptaan keadaan lainnya misalnya, konsumen terlebih dahulu membeli suatu produk baru setelah membentuk kepercayaan serta perilaku selanjutnya (Mowen dan Minor). Adapun tujuan penelitian ini adalah untuk mengetahui tingkat kepercayaan dan kualitas situs pada minat beli produk di e-commerce Bukalapak.

\section{KAJIAN PUSTAKA}

\section{E-commerce}

Perdagangan elektronik (e-commerce) menurut Laudon (2012) adalah "the use of internet and the web to transact business" dapat disimpulkan bahwa $e$ commerce adalah melakukan perdagangan atau transaksi bisnis secara online dengan menggunakan media internet dan perangkat-perangkat online lainnya. Laudon (2012) membagi perdagangan elektronik (e-commerce) menjadi lima jenis yaitu :

1) Business-to-Consumer (B2C) E-commerce

2) Business-to-Business (B2B) E-commerce

3) Consumer-to-Consumer $(C 2 C)$ E-commerce

4) Peer-to-Peer (P2P) E-commerce

5) Mobile Commerce (M-commerce) 
Sedangkan menurut Sutabri (2012) ecommerce adalah "penyebaran, pembelian, penjualan, pemasaran barang dan jasa melalui sistem elektronik seperti internet atau televisi, www, atau jaringan computer lainnya". Ecommerce dapat melibatkan transfer dana elektornik, sistem inventori otomatis, dan sistem pengumpulan data otomatis. Sehingga dapat dikatakan bahwa e-commerce merupakan suatu pemasaran barang atau jasa melalui sistem informasi yang memanfaatkan teknologi informasi.

\section{Perilaku Konsumen}

Istilah perilaku erat hubungannya dengan objek yang studinya diarahkan pada permasalah manusia. Di bidang studi pemasaran, konsep perlaku konsumen secara terus menerus dikembangkan dengan berbagai pendekatan. Perilaku konsumen adalah tindakan yangn langsung terlibat dalam mendapatkan, mengonsumsi, dan menghabiskan produk atau jasa, termasuk proses keputusan yang mendahului dan menyusuli tindakan ini. Untuk memahami konsumen dan mengembangkan strategi pemasaran yang tepat kita harus memahami apa yang mereka pikirkan (kognisi), apa yang mereka rasakan (pengaruh), dan apa yang mereka lakukan (perilaku) NJ.Setiadi (2015).

Faktor yang mempengaruhi perilaku konsumen bisa dilihat dari faktor psikologis yaitu kepercayaan dan sikap, kepercayaan adalah suatu gagasan deskriptif yang dimiliki seseorang terhadap sesuatu (NJ.Setiadi, 2015). Perilaku konsumen adalah perilaku konsumen akhir, individu dan rumah tangga, yang membeli barang atau jasa untuk konsumsi pribadi [3]. Image yang buruk dapat juga mempengaruhi penerimaan orang lain dan bahkan rekan kerja [4].

\section{Kepercayaan Konsumen}

Kepercayaan merupakan pencitraan, orang bertindak atas kepercayaannya. [5] Trust adalah kepercayaan pihak tertentu terhadap yang lain dalam melakukan hunbungan transasksi berdasarkan suatu keyakinan bahwa orang yang dipercayainya tersebut akan memenuhi segala keajibannya secara baik sesuai dengan yang diharapkan. Menurut [6] bahwa kepercayaan konsumen berfokus kepada keyakinan konsumen terhadap pihak lain terkait produk yang dijual, dalam hal ini perusahaan atau ritel.menurut Deni Pranoto, (2014:14) kepercayaan adalah "factor penting dalam mengatasi krisis dan kesulitan antara rekan bisnis selain itu juga merupakan asset penting dalam mengembangkan hubungan jangka panjang antar organisasi. Buruknya kualitas pelayanan publik menimbulkan krisis kepercayaan di masyarakat terhadap birokrasi publik. [7]

\section{Indikator Kepercayaan Konsumen}

Dimensi kepercayaan menurut Mayer (dalam Rahmawati, 2013) adalah sebagai berikut:

1. Ability

Kemampuan adalah sekelompok keahlian, kompetensi dan karateristik yang memungkinkan satu pihak memiliki domain spesifik. Kemampuan lebih dari sekedar pelayanan terhadap individu, tetapi lebih pada semua aspek tentang bagaimana melakukan bisnis.

2. Benevolence

Benevolence adalah sejauh mana trustee ingin melakukan dan memberikan yang terbaik kepada trustor, terlepas dari motif keuntungan yang sifatnya egosentris. Benevolence merupakan dasar dari layanan jaringan sosial karena benevolence akan mengarahkan interaksi positif antar individu (Hsiao, dkk, 2010)

3. Integrity

Merupakan persepsi trustor bahwa trustee akan bertahan pada seperangkat prinsip yang telah diberikan kepada trustor. Apa yang telah diucapkan oleh trustee kepada trustor harus sama dengan tindakan yang akan trustee lakukan dan konsumen memiliki keingintahuan apakah trustee dapat melakukan hal yang sama seperti apa yang telah dijanjikannya.

\section{Kualitas Situs atau Website}

Menurut Furkonudin et al (2016) menyatakan bahwa kualitas dari suatu website dalam sebuah situs online shop merupakan faktor yang dapat mempengaruhi minat beli pelanggan. Klasifikasi ini dapat membantu para pemasar untuk mengenali dan lebih memahami potensi dari alat-alat online shopping yang digunakan.

Kualitas website tidak hanya penting untuk memasarkan suatu produk dan jasa saja tetapi juga untuk memberikan informasi - informasi lainnya yang menarik bagi pelanggan. Pengukuran kualitas website penelitian ini menggunakan metode Webqual yang mengevaluasi pada website e-commerce. Kualitas dapat dipahami sebagai kesesuaian dengan spesifikasinya, dan juga sebagai bentuk kepatuhan dengan tujuannya. Model Servqual didasarkan pada pendekatan reliabilitas, kepastian, nyata, empati dan daya tanggap. [8]

\section{Dimensi Kualitas Situs atau Website}

Menurut Hyejeong dan Niehm dalam Puspitasari, dkk. (2013), membagi dimensi kualitas website menjadi tiga yaitu: 
1. Informasi Kualitas website (information quality) kualitas informasi meliputi hal-hal seperti informasi uang akurat, bisa dipercaya, informasi terbaru dan mudah dimengerti

2. Kualitas desain website(site design quality) meliputi kemampuan web dalam memberikan tampilan atau interface yang dengan estetika dan fungsi maksimal. Mulai dari segi penataan informasi, tampilan menumenu, kejelasan informasi dan pemilihan warna web.

3. Kualitas pengguna (usability quality) meliputi kemudahan untuk dipelajari, kemudahan untuk dimengerti situs dalam pemberian informasiyang diharapkan pengguna, kemudahan dalam pengoperasian situs.

\section{Minat Beli}

Meldarianda \& lisan (2010) dalam [9] menyimpulkan bahwa yang dimaksud dengan minat beli konsumen adalah "suatu proses perencanaan pembelian suatu produk yang akan dilakukan oleh konsumen dengan mempertimbangkan beberapa hal, diantaranya adalah banyak unit produk yang dibutuhkan dalam periode waktu tertentu, merek dan sikap konsumen dalam mengkonsumsi produk tersebut. Sementara itu, Nugraha (2013) menjelaskan bahwa minat beli diperoleh dari suatu proses belajar dan proses pemikiran yang membentuk suatu persepsi. Minat yang muncul dalam melakukan pembelian menciptakan suatu motivasi yang terus terekam dalam benaknya dan menjadi suatu kegiatan yang sangat kuat yang pada akhirnya ketika seseorang konsumen harus memenuhi kebutuhannyaakan mengaktuliasasikan apa yang ada didalam benaknya itu.

Menurut Schiffman dan Kanuk (2007:228) dalam [10] mendefinisikan minat beli merupakan suatu model sikap seseorang terhadap objek barang yang sangat cocok dalam mengukur sikap terhadap golongan produk, jasa, atau merek tertentuMinat pembelian ini menciptakan suatu motivasi yang terus terekam dalam benak konsumen dan menjadi suatu keinginan yang sangat kuat sehingga pada akhirnya ketika seorang konsumen harus memenuhi kebutuhannya akan mengaktualisasikan apa yang ada didalam benaknya itu. [11]

Menurut kinear dan Taylor (Wicaksono, 2017) yaitu merupaka bagian dari komponen perilaku konsumen dalam sikap mengkonsumsi, kecenderungan responden untuk bertindak sebelum keputusan membeli benar-benar dilaksanakan.

\section{Indikator Minat beli}

Menurut Ferdinan dalam Wicaksono (2017) minat beli dapat diidentifikasikan melalui indikatorindikator sebagai berikut:

1. Minat Transaksional yaitu kecenderungan untuk membeli produk

2. Minat Referensial yaitu kecenderungan seseorang untuk mereferensikan produk kepada orang lain.

3. Minat Preferensial yaitu minat yang menggambarkan perilaku seseorang yang memiliki preferensial utama pada produk tersebut. Preferensi ini hanya dapat diganti jika terjadi sesuatu dengan produk preferensinya.

4. Minat Eksploratif minat ini mengambarkan perilaku seseorang yang selalu mencari informasi mengenai produk yang diminatinya dan mencari informasi untuk mendukung sifat-sifat positif dari produk tersebut.

\section{METODE PENELITIAN}

Menurut Sugiono (2014) metode penelitian pada dasarnya merupakan cara ilmiah untuk mendapatkan data dengan tujuan dan kegunaan tertentu. Berdasarkan hal tersebut terdapat empat kata kunci yang perlu diperhatikan yaitu cara ilmiah, data, tujuan dan kegunaan. Menurut Darmadi (2013) metode penelitian adalah suatu cara ilmiah untuk mendapatkan data dengan tujuan kegunaan tertentu. Berdasarkan definisi diatas maka dapat disimpulkan bahwa metode penelitian adalah suatu cara yang digunakan oleh peneliti dalam mengumpulkan data dengan tujuan dan kegunaan tertentu dengan menggunakan metode kuantitatif.

Penelitian kuantitatif dilakukan dengan menggunakan kuesioner atau angket sebagai sumber data utama. Dalam penelitian survey, responden diminta untuk memberikan jawaban singkat yang sudah tertulis di dalam kuesioner atau angket untuk kemudian jawaban dari seluruh responden tersebut diolah menggunakan metode analisis kuantitatif.

\section{Populasi}

(Sugiyono, 2016) menyatakan populasi adalah wilayah generalisasi yang terdiri atas objek dan subjek yang mempunyai kualitas dan karakteristik tertentu yang ditetapkan oleh peneliti untuk dipelajari dan kemudian ditarik kesimpulannya. Populasi yang digunakan dalam 
penelitian ini adalah pengguna internet yang pernah belanja online minimal satu kali ataupun yang tidak pernah belanja di situs Bukalapak. Dan jumlah pengunjung internet di Indonesia tidak terhingga.

\section{Sampel}

Sugiyono (2016:120) menjelaskan "sampel adalah bagian dari jumlah dan karakteristik yang dimiliki oleh populasi tersebut". Metode pengambilan sampel ditentukan dengan menggunakan rumus (Rao Purba dalam Widiyanto, 2008). Jumlah konsumen Bukalapak yang tak terhingga sehingga penelitian ini menggunakan rumus sampel Rao Purba.

$$
\mathrm{n}=\frac{z^{2}}{4(m o e)^{2}}
$$

Diketahui :

$\mathrm{n}=$ Jumlah Sampel

$\mathrm{Z}=$ Tingkat Distribusi Normal

Moe $=$ Margin of Error Max, yaitu tingkat kesalahan maksimal pengambilan sampel yang masih dapat ditoleransi atau yang diinginkan.

Dengan menggunakan margin of error max sebesar 10\%, maka jumlah sample minimal yang dapat diambil sebesar:

$\mathrm{n}=\frac{1,96^{2}}{4(0,10)^{2}}=96,04$ atau 96; dan dibulatkan menjadi 100

Berdasarkan hasil perhitungan, maka jumlah sampel yang akan digunakan sebanyak 96,04 responden dan dibulatkan menjadi 100 responden. Karena dasar itulah peneliti menentukan jumlah sampel dalam penelitian ini sebanyak 100 responden.

\section{HASIL DAN PEMBAHASAN}

\section{Pembahasan Validitas dan Realibilitas}

Uji validitas menunjukan derajat ketetapan antara data yang terjadi pada objek penelitian dengan daya yang dapat dilaporkan oleh peneliti. Jadi suatu penelitian dikatakan valid apabila terdapat kesamaan antara data yang terkumpul dengan data yang sesungguhnya terjadi pada objek yangditeliti. Suatu pernyataan dinyatakan valid apabila memiliki nilai $r$ hitung > r-tabel $(0,361)$. Hasil pengujian validitas, disajikan pada tabel berikut di bawah ini:

\begin{tabular}{ccccc}
\multicolumn{4}{c}{ Hasil Uji Validitas Instrumen } \\
\hline Variabel & $\begin{array}{c}\text { No } \\
\text { Item }\end{array}$ & $\begin{array}{c}\text { r- } \\
\text { hitung }\end{array}$ & $\begin{array}{c}\text { r- } \\
\text { tabel }\end{array}$ & $\begin{array}{c}\text { Keterang } \\
\text { an }\end{array}$ \\
\hline $\begin{array}{c}\text { Kepercayaa } \\
\text { n }\left(\mathbf{X}_{\mathbf{1}}\right)\end{array}$ & 1 & 0.691 & 0.361 & Valid \\
\cline { 2 - 5 } & 2 & 0.599 & 0.361 & Valid \\
\hline & 3 & 0.516 & 0.361 & Valid \\
\hline
\end{tabular}

\begin{tabular}{|c|c|c|c|c|}
\hline & 4 & 0.547 & 0.361 & Valid \\
\hline & 5 & 0.722 & 0.361 & Valid \\
\hline & 6 & 0.505 & 0.361 & Valid \\
\hline \multirow{6}{*}{$\begin{array}{c}\text { Kualitas } \\
\text { Situs }\left(\mathbf{X}_{2}\right)\end{array}$} & 1 & 0.818 & 0.361 & Valid \\
\hline & 2 & 0.843 & 0.361 & Valid \\
\hline & 3 & 0.822 & 0.361 & Valid \\
\hline & 4 & 0.789 & 0.361 & Valid \\
\hline & 5 & 0.812 & 0.361 & Valid \\
\hline & 6 & 0.689 & 0.361 & Valid \\
\hline \multirow{4}{*}{$\begin{array}{l}\text { Minat Beli } \\
(\mathbf{Y})\end{array}$} & 1 & 0.832 & 0.361 & Valid \\
\hline & 2 & 0.887 & 0.361 & Valid \\
\hline & 3 & 0.876 & 0.361 & Valid \\
\hline & 6 & 0.753 & 0.361 & Valid \\
\hline
\end{tabular}

Berdasarkan rekapitulasi hasil pengujian validitas instrumen di atas, terlihat bahwa seluruh pernyataan yang diajukan dalam mengukur kepercayaan, kualitas situs dan minat beli memiliki nilai r-hitung > rtabel $(0,361)$ yang menunjukan bahwa seluruh pernyataan yang diajukan sudah melakukan fungsi ukurnya, dengan kata lain dinyatakan valid.

\section{Uji Reliabilitas}

Alat ukur selain harus valid juga harus memiliki reliabilitas atau keandalan. Suatu alat ukur dapat dikatakan andal jika alat ukur tersebut digunakan berulang kali akan memberikan hasil yang relatif sama (tidak berbeda jauh). Pengujian reliabilitas ini dimaksudkan untuk mengukur sejauh mana skala mampu menciptakan hasil yang konsisten jika pengukuran terhadap karakteristik tertentu. Dalam penelitian ini, untuk menguji tingkat konsistensi dari alat ukur penelitian digunakan metode alpha cronbach. Suatu konstruk dapat diterima jika memilki nilai koefisien reliabilitas yang lebih besar atau sama dengan 0,6.. Hasil perhitungan koefisien reliabilitas dapat dilhat pada tabel berikut:

\section{Hasil Pengujian Reliabilitas Instrumen} Koefesi en $\quad$ Titik Ket

\begin{tabular}{cccc} 
Variabel & $\begin{array}{c}\text { Reliabil } \\
\text { itas }\end{array}$ & Kritis & Ket \\
\hline $\begin{array}{c}\text { Kepercayaan } \\
\left(\mathbf{X}_{\mathbf{1}}\right)\end{array}$ & 0.627 & 0.600 & $\begin{array}{c}\text { Reliabe } \\
1\end{array}$ \\
\hline
\end{tabular}




\begin{tabular}{cccc}
\hline $\begin{array}{c}\text { Kualitas Situs } \\
\left(\mathbf{X}_{2}\right)\end{array}$ & 0.883 & 0.600 & $\begin{array}{c}\text { Reliabe } \\
1\end{array}$ \\
\hline Minat Beli $(\mathbf{Y})$ & 0.851 & 0.600 & $\begin{array}{c}\text { Reliabe } \\
1\end{array}$ \\
\hline
\end{tabular}

Berdasarkan hasil pengujian reliabilitas instrumen di atas, terlihat bahwa nilai koefisien reliabilitas yang diperoleh masing-masing variabel > 0,6 yang menunjukan bahwa alat ukur yang digunakan sudah menunjukan keandalannya sehingga sudah memenuhi syarat untuk digunakan dalam penelitian.

\section{Uji Normalitas Data}

Uji normalitas bertujuan untuk mengetahui apakah variabel dependen, independen atau keduanya berdistribusi normal, mendekati normal atau tidak. model regresi yang baaik hendaknya berdistribusi normal atau mendekati normal. Untuk mendeteksi ada tidaknya pelanggaran asumsi normalitas dapat dilihat dengan menggunakan metode Kolmogorov-Smirnov (KS) dengan ketentuan sebagai berikut:

a. Jika probabilitas $>0,05$ maka distribusi dari populasi adalah normal.

b. Jika probabilitas $<0,05$ maka distribusi dari populasi adalah tidak normal.

\section{Hasil Uji Normalitas}

\begin{tabular}{|c|c|c|c|c|}
\hline \multicolumn{5}{|c|}{ One-Sanqle Kolmogorov-Smirnov Test } \\
\hline & & Kepercayaan & Kualitas Situs & Minat Beli \\
\hline $\mathrm{N}$ & & 100 & 100 & 100 \\
\hline \multirow{2}{*}{ Normal Parameters ${ }^{2, b}$} & Mean & 18.6216 & 19.7575 & 14.4165 \\
\hline & Std Deviation & 2.67552 & 4.56811 & 2.91535 \\
\hline \multirow[t]{3}{*}{ Most Extreme Differences } & Absolute & .061 & .079 & .101 \\
\hline & Positive & .061 & .070 & .101 \\
\hline & Negative & -.047 & -.079 & -100 \\
\hline Kolmogorov-Smirnov $Z$ & & .613 & .792 & 1.006 \\
\hline Asymp. Sig. (2-triled) & & .847 & .557 & .264 \\
\hline
\end{tabular}

Dari hasil pengujian normalitas data yang disajikan pada tabel di atas, terlihat bahwa nilai probabilitas (sig) yang diperoleh masing-masing variabel sebesar > 0,05 yang menunjukan bahwa data yang digunakan memiliki sebaran yang normal. Dengan kata lain asumsi normalitas data terpenuhi.

\section{Uji Multikolinieritas}

Uji multikolinearitas berguna untuk mengetahui apakah pada model regresi yang diajukan telah ditemukan korelasi kuat antar variabel independen. Jika terjadi korelasi kuat, maka terdapat masalah multikolinearitas yang harus diatasi. Model regresi yang baik yaitu tidak terdapatnya multikolinearitas atau tidak terjadi korelasi yang kuat antar variabel independen. Untuk melihat nilai multikolinieritas dapat dilihat dengan nilai tolerance dan Variance Inflation Factor
(VIF). Jika nilai tolerance > 0,10 dan VIF < 10, maka tidak terjadi multikolinieritas. Sebaliknya jika tolerance $<0,10$ dan VIF > 10 maka terjadi multikolinieritas. Dari pengolahan data yang telah dilakukan, diperoleh hasil uji multikolinieritas sebagai berikut:

\section{Hasil Uji Multikolinieritas}

Coefficients $^{2}$

\begin{tabular}{|ll|r|c|}
\hline \multirow{2}{*}{ Model } & & \multicolumn{2}{|c|}{ Collinearity Statistics } \\
\cline { 3 - 4 } & & Tolerance & \multicolumn{1}{l|}{ VIF } \\
\hline 1 & Kepercayaan & .891 & 1.122 \\
& Kualitas Situs & .891 & 1.122 \\
\hline
\end{tabular}

a. Dependent Variable: Minat Beli

Tabel di atas menunjukan hasil pengujian multikolinieritas data. Dari data yang disajikan pada table di atas, terlihat bahwa nilai tolerance yang diperoleh kedua variabel bebas masing-masing sebesar 0,947 > 0,1 dan Variance Inflation Factor (VIF) kurang dari 10. Hal ini menunjukan bahwa tidak ditemukan adanya korelasi yang kuat diantara variabel bebas, sehingga asumsi multikolinieritas data terpenuhi.

\section{Uji Heteroskedastisitas}

Uji heteroskedastisitas berguna untuk mengetahui apakah pada model regresi terjadi ketidaksamaan varians dari residual suatu pengamatan dengan pengamatan lainnya. Jika variance dari residual satu pengamatan ke pengamatan lain tetap, maka disebut Homoskesatisitas dan jika berbeda disebut Heteroskedastisitas. Untuk mendeteksi ada tidaknya pelanngaran heteroskedastisitas, dapat dilihat dengan menggunakan metode scatter plot dengan ketentuan sebagai berikut:

a. jika ada pola tertentu seperti titik-titik (point-point) yang ada membentuk suatu pola tertentu yang teratur (bergelombang, melebar, kemudian menyempit) maka telah terjadi heteroskedastisitas

b. jika tidak ada pola yang jelas serta titik-titik menyebar diatas dan di bawah angka nol pada sumbu Y maka tidak terjadi heteroskedastisitas. 


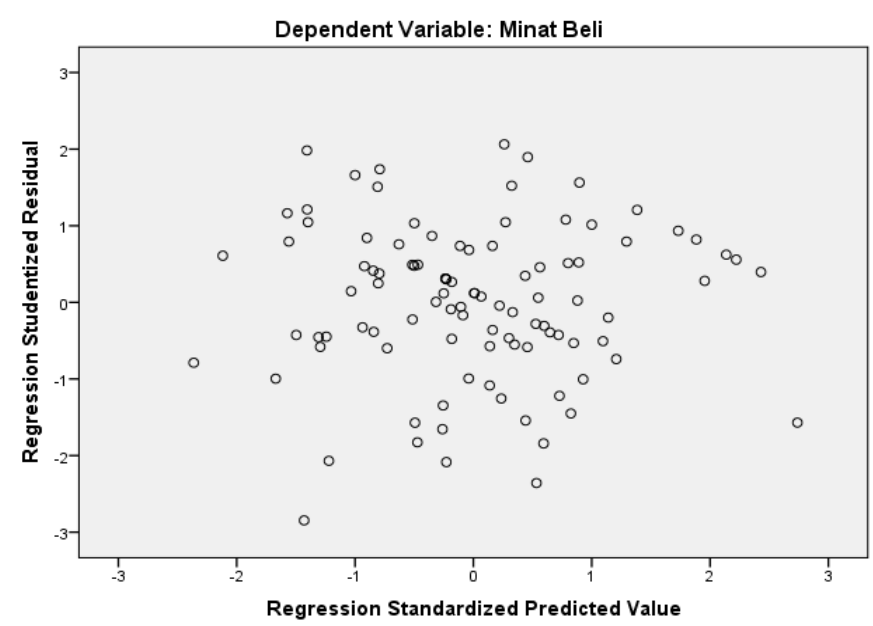

\section{Hasil Uji Heteroskedastisitas}

Gambar di atas menunjukan hasil pengujian heteroskedastisitas dengan menggunakan metode grafik scatter plot. Dari gambar tersebut terlihat bahwa titiktitik yang diperoleh membentuk pola acak tidak beraturan serta menyebar diatas dan dibawah angka nol (0) pada sumbu Y, sehingga dalam model regresi yang akan dibentuk tidak ditemukan adanya pelanggaran heteroskedastisitas, dengan kata varians residual bersifat homokedastisitas.

\section{Persamaan Regresi Linier Berganda}

Model persamaan regresi linier berganda yang akan dibentuk adalah sebagai berikut:

$$
\mathrm{Y}=\mathrm{a}+\beta_{1} \mathrm{X}_{1}+\beta_{2} \mathrm{X}_{2}
$$

Keterangan :

$$
\begin{array}{ll}
\mathrm{a} & : \text { Konstanta } \\
\mathrm{Y} & : \text { Minat Beli } \\
\mathrm{X}_{1} & : \text { Kepercayaan } \\
\mathrm{X}_{2} & : \text { Kualitas Situs }
\end{array}
$$

$b_{1}$ dan $b_{2}$ : Koefisien regresi

\begin{tabular}{|c|c|c|c|c|c|c|}
\hline \multirow[b]{2}{*}{ Model } & & \multicolumn{2}{|c|}{ Unstandardized Coefficients } & \multirow{2}{*}{$\begin{array}{c}\begin{array}{c}\text { Standardized } \\
\text { Coefficients }\end{array} \\
\text { Beta } \\
\end{array}$} & \multirow[b]{2}{*}{$t$} & \multirow[b]{2}{*}{ Sig. } \\
\hline & & $B$ & Stc. Error & & & \\
\hline \multirow[t]{3}{*}{1} & (Constant) & 2.303 & 1.725 & & 1.335 & .185 \\
\hline & Kepercayaan & .382 & .093 & .351 & 4.116 & .000 \\
\hline & Kualitas Situs & .253 & .054 & 396 & 4.644 & .000 \\
\hline
\end{tabular}

Berdasarkan hasil pengolahan data dengan menggunakan SPSS, diperoleh hasil sebagai berikut:

\section{Persamaan Regresi Linier Berganda}

Coefficients $^{2}$

a. Dependent Variable: Minat Beli

Dari tabel output di atas diperoleh nilai a sebesar 2,303, $\beta_{1}$ sebesar 0,382 dan $\beta_{2}$ sebesar 0,253. Dengan demikian, persamaan regresi linier berganda yang akan dibentuk adalah sebagai berikut:

$$
\mathrm{Y}=2,303+0,382 \mathrm{X}_{1}+0,253 \mathrm{X}_{2}
$$

Dari hasil persamaan regresi linier berganda tersebut masing-masing variabel dapat diinterpretasikan sebagai berikut:

a. Konstanta sebesar 2,303 menunjukan bahwa ketika kepercayaan dan kualitas situs bernilai nol (0) dan tidak ada perubahan, maka minat beli diprediksi akan bernilai sebesar 2,303.

b. Variabel $X_{1}$ yaitu kepercayaan memiliki nilai koefisien regresi sebesar 0,382 menunjukan bahwa ketika kepercayaan meningkat, maka minat beli diprediksi akan meningkat sebanyak 0,382 kali.

c. Variabel $\mathrm{X}_{2}$ yaitu kualitas situs memiliki nilai koefisien regresi sebesar 0,253, menunjukan bahwa ketika kualitas situs ditingkatkan, diprediksi akan meningkatkan minat beli sebanyak 0,253 kali.

\section{Analisis Korelasi}

Analisis korelasi bertujuan untuk mengukur kekuatan (asosiasi) hubungan antara variabel bebas dengan variabel terikat, dalam hal ini untuk melihat hubungan antara kepercayaan $\left(\mathrm{X}_{1}\right)$ dan kualitas situs $\left(\mathrm{X}_{2}\right)$

\begin{tabular}{|c|c|c|c|c|}
\hline Model & $\mathrm{R}$ & RSquare & $\begin{array}{c}\text { Adjusted R } \\
\text { Square }\end{array}$ & $\begin{array}{l}\text { Std. Error of } \\
\text { the Estimate }\end{array}$ \\
\hline 1 & $.610^{2}$ & .372 & .359 & 2.3348 \\
\hline
\end{tabular}
dengan minat beli (Y). Teknik analisis korelasi yang digunakan dalam penelitian ini menggunakan analisis korelasi pearson product moment.

\section{Hasil Analisis Korelasi}

Model Sumuary

Berdasarkan tabel di atas, diketahui bahwa nilai korelasi yang diperoleh antara kepercayaan dan kualitas situs dengan minat beli adalah sebesar 0,610. Nilai korelasi sebesar 0,610 jika mengacu pada kriteria interpretasi koefisien korelasi termasuk kedalam kategori hubungan yang kuat, berada dalam kelas interval antara 0,600-0,799.

\section{Koefisien Determinasi}

Koefisien Determinasi $\left(\mathrm{R}^{2}\right)$ digunakan untuk mengukur seberapa jauh kemampuan model dalam menerangkan variasi variabel dependen. Nilai koefisien determinasi adalah antara nol dan satu. Nilai R2 yang kecil berarti kemampuan variabel-variabel independen dalam menjelaskan variasi variabel independen amat 
terbatas. Nilai yang mendekati variabel-variabel independen memberikan hampir semua informasi yang dibutuhkan untuk memprediksi variasi variabel dependen. Dengan menggunakan SPSS, koefisien determinasi dapat dilihat sebagai berikut:

Koefisien Determinasi Simultan

Model Sumurary
\begin{tabular}{|l|c|c|c|c|}
\hline Model & R & RSquare & $\begin{array}{c}\text { Adjusted R } \\
\text { Square }\end{array}$ & $\begin{array}{c}\text { Std. Error of } \\
\text { the Estimate }\end{array}$ \\
\hline 1 & $610^{8}$ & 372 & 359 & 2.33487 \\
\hline
\end{tabular}
a. Predictors: (Constant), Kualitas Situs, Kepercayaan
b. Dependent Variable: Minat Beli

Berdasarkan tabel di atas, diperoleh informasi bahwa nilai koefisien korelasi atau $(\mathrm{R})$ yang diperoleh sebesar 0,610. Dengan demikian koefisien determinasi dapat dihitung sebagai berikut:

$\mathrm{Kd}=(r)^{2} \times 100 \%$

$\mathrm{Kd}=(0,610)^{2} \times 100 \%$

$\mathrm{Kd}=37,2 \%$

Berdasarkan hasil perhitungan di atas, diketahui bahwa nilai koefisien determinasi yang diperoleh sebesar $37,2 \%$. Hal ini menunjukan bahwa kedua variabel bebas yang diuji yang terdiri dari kepercayaan dan kualitas situs memberikan kontribusi terhadap minat beli sebesar $37,2 \%$, sedangkan sisanya sebesar $62,8 \%$ lainnya merupakan kontribusi dari variabel lain yang tidak diteliti. Sedangkan untuk melihat besarnya kontribusi pengaruh yang diberikan oleh masing-masing variabel bebas terhadap variabel terikat, maka dilakukan perhitungan sebagai berikut:

\section{Koefisien Determinasi Parsial}

\section{Coefficients $^{2}$}

\begin{tabular}{|ll|r|r|}
\hline \multirow{2}{*}{ Model } & \multicolumn{2}{|c|}{$\begin{array}{c}\text { Standardized } \\
\text { Coefficients }\end{array}$} & Correlations \\
\cline { 3 - 4 } & \multicolumn{2}{|c|}{ Beta } & Zero-order \\
\hline 1 & Kepercayaan & .351 & .481 \\
& Kualitas Situs & .396 & .512 \\
\hline
\end{tabular}

a. Dependent Variable: Minat Beli

Berdasarkan output di atas dilakukan perhitungan sebagai berikut:

Pengaruh $\mathrm{X}_{1}$ terhadap $\mathrm{Y}=0,351 \times 0,481=0,169$ atau $16,9 \%$

Pengaruh $\mathrm{X}_{2}$ terhadap $\mathrm{Y}=0,396 \times 0,512=0,203$ atau $20,3 \%$

Berdasarkan hasil perhitungan di atas, diketahui bahwa kualitas situs $\left(\mathrm{X}_{2}\right)$ memberikan kontribusi paling dominan terhadap minat beli $(\mathrm{Y})$ dengan kontribusi yang diberikan sebesar 20,3\%, sedangkan 16,9\% lainnya diberikan oleh kepercayaan $\left(\mathrm{X}_{1}\right)$.

\section{Pengujian Hipotesis}

Pengujian Hipotesis Parsial

Pengujian Hipotesis Parsial $\mathbf{X}_{\mathbf{1}}$

$\mathrm{H}_{0}: \beta_{1}=0$ Artinya, secara parsial kepercayaan tidak berpengaruh signifikan terhadap minat beli produk $E$ Commerce Bukalapak.

$\mathrm{H}_{\mathrm{a}}: \beta_{1} \neq 0$ Artinya, secara parsial kepercayaan berpengaruh signifikan terhadap minat beli produk $E$ Commerce Bukalapak.

Dengan taraf signifikansi 0,05

Kriteria : Tolak $\mathrm{H}_{0}$ jika t hitung > dari t tabel, terima dalam hal lainnya

Dengan menggunakan SPSS, diperoleh hasil uji hipotesis parsial $\mathrm{X}_{1}$ sebagai berikut:

Pengujian Hipotesis Parsial $\mathbf{X}_{1}$

\begin{tabular}{|c|c|c|c|c|c|c|}
\hline \multicolumn{7}{|c|}{ Coefficients $^{2}$} \\
\hline \multirow[b]{2}{*}{ Mod } & & \multicolumn{2}{|c|}{ Unstandarclized Coefficients } & $\begin{array}{l}\text { Standardized } \\
\text { Coefficients }\end{array}$ & \multirow[b]{2}{*}{$t$} & \multirow[b]{2}{*}{ Sig. } \\
\hline & & $B$ & Std. Error & Beta & & \\
\hline 1 & (Constant) & 2.303 & 1.725 & & 1.335 & .185 \\
\hline & Kepercayaan & 382 & .093 & 351 & 4.116 & .000 \\
\hline & Kualitas Situs & .253 & .054 & 396 & 4.644 & .000 \\
\hline
\end{tabular}

Berdasarkan tabel di atas, diketahui bahwa nilai t-hitung yang diperoleh variabel kepercayaan $\left(\mathrm{X}_{1}\right)$ sebesar 4,116. Nilai ini akan dibandingkan dengan nilai t-tabel pada tabel distribusi t. Dengan $\alpha=0,05, \mathrm{df}=\mathrm{n}-\mathrm{k}-$ $1=100-2-1=97$, diperoleh nilai t-tabel untuk pengujian dua pihak sebesar $\pm 1,985$. Dari nilai-nilai di atas terlihat bahwa nilai t-hitung yang diperoleh sebesar 4,116, berada diluar nilai t-tabel $(-1,985$ dan 1,985$)$. Sesuai dengan kriteria pengujian hipotesis bahwa $\mathrm{H}_{0}$ ditolak dan $\mathrm{H}_{\mathrm{a}}$ diterima, artinya secara parsial kepercayaan berpengaruh signifikan terhadap minat beli produk $E$ Commerce Bukalapak.

Pengujian Hipotesis Parsial $\mathbf{X}_{\mathbf{2}}$

$\mathrm{H}_{0}: \beta_{2}=0 \quad$ Artinya, secara parsial kualitas situs tidak berpengaruh signifikan terhadap minat beli produk E-Commerce Bukalapak.

$\mathrm{H}_{\mathrm{a}}: \beta_{2} \neq 0 \quad$ Artinya, secara parsial kualitas situs berpengaruh signifikan terhadap minat beli produk $E$ Commerce Bukalapak.

Dengan taraf signifikansi 0,05

Kriteria : Tolak $\mathrm{H}_{0}$ jika $\mathrm{t}$ hitung > dari $\mathrm{t}$ tabel, terima dalam hal lainnya

Dengan menggunakan SPSS, diperoleh hasil uji hipotesis parsial $\mathrm{X}_{2}$ sebagai berikut: 
Pengujian Hipotesis Parsial $\mathbf{X}_{2}$

Coefficients $^{2}$

\begin{tabular}{|c|c|c|c|c|c|c|}
\hline \multirow[b]{2}{*}{ Model } & & \multicolumn{2}{|c|}{ Unstandardized Coefficients } & \multirow{2}{*}{$\begin{array}{c}\begin{array}{c}\text { Standardized } \\
\text { Coefficients }\end{array} \\
\text { Beta }\end{array}$} & \multirow[b]{2}{*}{$t$} & \multirow[b]{2}{*}{ Sig. } \\
\hline & & $B$ & Std. Error & & & \\
\hline \multirow[t]{3}{*}{1} & (Constant) & 2.303 & 1.725 & & 1.335 & .185 \\
\hline & Kepercayaan & 382 & .093 & 351 & 4.116 & .000 \\
\hline & Kualitas Situs & .253 & .054 & 396 & 4.644 & .000 \\
\hline
\end{tabular}

Berdasarkan tabel di atas, diketahui bahwa nilai t-hitung yang diperoleh variabel kualitas situs $\left(\mathrm{X}_{2}\right)$ sebesar 4,644. Nilai ini akan dibandingkan dengan nilai t-tabel pada tabel distribusi t. Dengan $\alpha=0,05, \mathrm{df}=\mathrm{n}-\mathrm{k}$ $1=100-2-1=97$, diperoleh nilai t-tabel untuk pengujian dua pihak sebesar $\pm 1,985$. Dari nilai-nilai di atas terlihat bahwa nilai t-hitung yang diperoleh sebesar 4,644, berada diluar nilai t-tabel $(-1,985$ dan 1,985$)$. Sesuai dengan kriteria pengujian hipotesis bahwa $\mathrm{H}_{0}$ ditolak dan $\mathrm{H}_{\mathrm{a}}$ diterima, artinya secara parsial kualitas situs berpengaruh signifikan terhadap minat beli produk $E$ Commerce Bukalapak.

\section{Pengujian Hipotesis Simultan}

Untuk membuktikan apakah kedua variabel bebas yang terdiri dari kepercayaan dan kualitas situs berpengaruh signifikan terhadap minat beli produk $E$ Commerce Bukalapak, maka dilakukan pengujian hipotesis dengan rumusan hipotesis sebagai berikut:

$\mathrm{H}_{0}: \beta_{1}=\beta_{2}=0$, artinya secara simultan, kedua variabel bebas yang terdiri dari kepercayaan dan kualitas situs tidak berpengaruh signifikan terhadap minat beli produk E-Commerce Bukalapak.

$\mathrm{H}_{\mathrm{a}}: \beta_{1} \neq \beta_{2} \neq 0$, artinya secara simultan, kedua variabel bebas yang terdiri dari kepercayaan dan kualitas situs berpengaruh signifikan terhadap minat beli produk $E$ Commerce Bukalapak.

Taraf signifikansi $(\alpha): 0,05$

Kriteria uji : tolak $\mathrm{H}_{0}$ jika nilai t-hitung > t-tabel, $\mathrm{H}_{\mathrm{a}}$ terima

Nilai statistik uji $\mathrm{F}$ dapat diketahui dari tabel output berikut:

\section{Pengujian Hipotesis Simultan}

ANOVA $^{2}$

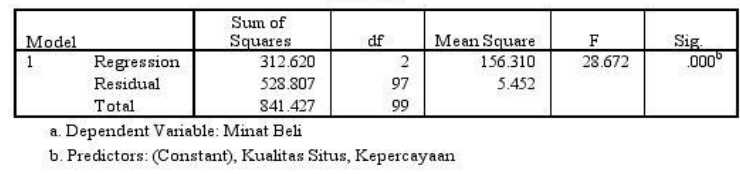

Berdasarkan hasil perhitungan di atas, terlihat bahwa nilai F-hitung yang diperoleh sebesar 28,672. Nilai ini akan dibandingkan dengan nilai F-tabel pada tabel distribusi F. Dengan $\alpha=0,05, \mathrm{db}_{1}=2$ dan $\mathrm{db}_{2}=97$, diperoleh nilai F-tabel sebesar 3,090. Dari nilai-nilai di atas, terlihat bahwa nilai $F_{\text {hitung }}(28,672)>F_{\text {tabel }}(3,090)$, sesuai dengan kriteria pengujian hipotesis bahwa $\mathrm{H}_{0}$ ditolak dan $\mathrm{H}_{\mathrm{a}}$ diterima. Artinya secara simultan kedua variabel bebas yang terdiri dari kepercayaan dan kualitas situs berpengaruh signifikan terhadap minat beli produk E-Commerce Bukalapak.

\section{KESIMPULAN}

Berdasarkan hasil analisis data dan pembahasan yang telah dijelaskan pada bab sebelumnya, maka penulis mengambil beberapa kesimpulan secara umum, kepercayaan konsumen (X1) pada e-commerece Bukalapak tergolong baik hal ini dibuktikan dari 100 responden dengan rentan nilai skor kepercayaan konsumen dalam kondisi baik dan dapat memenuhi keinginan konsumen Bukalapak. Berikutnya, kualitas situs pada e-commerece Bukalapak tergolong baik. hal ini dibuktikan dari 100 responden dengan rentan nilai skor Kualitas situs dalam kondisi baik dan dapat memenuhi keinginan konsumen Bukalapak. Minat beli konsumen terhadap produk e-commerece Bukalapak tergolong tinggi. Secara parsial, kepercayaan berpengaruh signifikan terhadap minat beli pada situs commerece Bukalapak dengan kontribusi yang diberikan sebesar $16,9 \%$. Kualitas situs berpengaruh signifikan terhadap minat beli pada situs -commerece Bukalapak dengan kontribusi yang diberikan sebesar 20,3\%. Secara simultan, kepercayaan dan kualitas situs berpengaruh signifikan terhadap minat beli pada situs -commerece Bukalapak dengan kontribusi yang diberikan sebesar $37,2 \%$, sedangkan sisanya sebesar $62,8 \%$ lainnya merupakan kontribusi dari variabel lain yang tidak diteliti.

\section{REFERENSI}

[1] I. Sidharta and B. Suzanto, "Pengaruh Kepuasan Transaksi Online Shopping Dan Kepercayaan Konsumen Terhadap Sikap Serta Perilaku Konsumen Pada E-Commerce," J. Comput. Bisnis, vol. 9, no. 1, pp. 23-36, 2015.

[2] H. K. J. A. Jarrell D. Collier, Michael P. Davenport, "Search@Www.Google.Com." 
2017.

[3] E. D. Koestanti and K. Nainggolan, "FaktorFaktor Bauran Pemasaran, Yang Mempengaruhi Keputusan Konsumen Untuk Membeli Produk Kosmetik Oriflame," Konf. Nas. Ilmu Pengetah. dan Teknol., vol. 2, no. 1, p. 9-MN.20, 2015.

[4] H. Rohaeni, A. S. Hikmah, and R. Rahmayani, "Be Good Atitude Dalam Berpenampilan Pada UMKM 'Mang Piat' Kabupaten Bandung Barat," J. Pengabdi. Kpd. Masy., vol. 1, no. 1, pp. 142-148, 2018.

[5] D. P. Alamsyah and R. Anugrah, "Membangun Kepercayaan Nasabah Pada Internet Banking," Jl. Terusan Sekol. Int. Antapani Bandung, vol. 40282, no. 1, pp. 464-473, 2015.

[6] D. P. Alamsyah, "Kepercayaan konsumen pada produk organik," Ecodemica, vol. IV, no. 2, p. 148, 2016.

[7] R. yuli Angliawati, "Peran Remunerasi Terhadap Kualitas Pelayanan Publik :

Theoretical Review," vol. IV, no. 2, pp. 203213, 2016.

[8] H. Yuliansyah, "Bakery Dan Kualitas Layanan Dalam Meningkarkan Minat Beli Konsumen," $J$. Ecodemica, vol. II, no. 2, pp. 211-221, 2014.

[9] R. A. dan W. Adidarma, "Pengaruh Kepercayaan Dan Risiko Pada Minat Beli Belanja Online," J. Manaj. dan Bisnis Sriwij., vol. 14, pp. 1-14, 2016.

[10] A. Solihat, "No Title," pp. 1-10, 2016.

[11] Elsa and D. P. Alamsyah, "Pengaruh Citra Merek dan Pandangan Kualitas Terhadap Kepercayaan Konsumen Pada McDonald's Bandung," Ecodemica, vol. 1, no. 1, pp. 75-84, 2013. 